\title{
The Influence of Intelligence and Personality on the Use of Soft Skills in Research Projects among Final Year University Students: A Case Study
}

\author{
Mahendrenath Motah \\ University of Technology, La Tour Koenig, \\ Pointe aux Sables, Mauritius
}

\author{
mmotah@utm.intnet.mu
}

\begin{abstract}
The paper examines the moderating influence of the "Big Five" model of personality, emotional intelligence, and the impact of multiple intelligences, on the use of soft skills among final year students. The present work investigates the variables which affect students in the elaboration of their research projects during their final year of study.

187students reading for their final years were asked to fill out questionnaires comprising questions on the personality traits as proposed in the Big Five model and on Multiple Intelligences.

This study provides information about how young students use soft skills in their work, and how multiple intelligences and their personality influence the preparation and presentation of their final year project.
\end{abstract}

Key words: Personality, soft skills, intelligence, big five model, research project, multiple intelligences.

\section{Introduction}

The relationships between the use of soft skills and the influence of multiple intelligences and personality among students reading for their final year of study at undergraduate level is an area of research which has prompted us to further our investigation. The results obtained are presented for a critical appraisal and suggestions from academics interested in the matter. Several papers available from different sources and others presented at international conferences have dealt with these issues, but owing to the complexity of the concepts of intelligence and personality there have been important challenges posed to the results obtained. It has proved to be difficult to draw plausible conclusions from the surveys, research and reviews presented in these papers. We do not pretend having found the answer, but the present work sheds some light on issues related to

Material published as part of this publication, either on-line or in print, is copyrighted by the Informing Science Institute. Permission to make digital or paper copy of part or all of these works for personal or classroom use is granted without fee provided that the copies are not made or distributed for profit or commercial advantage AND that copies 1) bear this notice in full and 2) give the full citation on the first page. It is permissible to abstract these works so long as credit is given. To copy in all other cases or to republish or to post on a server or to redistribute to lists requires specific permission and payment of a fee. Contact Publisher@InformingScience.org to request redistribution permission. these concepts and open avenues for further research and provides a platform for collaboration among academics interested to join efforts and share ideas and views on the topics. The importance of these concepts to lecturers and students cannot be minimized as they provide the support on which new knowledge is transmitted to students and learners at all levels of the education ladder. We wish to share the findings of 
the research with other colleagues and expect to enrich ourselves through their reactions and by sharing our views and findings.

\section{Methodology}

\section{Study Group}

The study was carried out with students reading for their final year in two schools: one with emphasis on Information Technology, and the other with management as the major field of study. Table 1 shows the constitution of the two groups.

Table 1 - Sample

\begin{tabular}{|l|l|c|l|l|}
\hline \multirow{2}{*}{ SCHOOL } & \multicolumn{2}{|c|}{$\begin{array}{c}\text { No. of Students } \\
\text { (Age range: } \\
19-27 \text { yrs) }\end{array}$} & \multirow{2}{*}{ Total } & \multirow{2}{*}{$\%$} \\
\cline { 2 - 4 } & Boys & Girls & & \\
\hline Information Technology & 37 & 35 & 72 & 38.5 \\
\hline Management & 64 & 51 & 115 & 61.5 \\
\hline Total & 111 & 86 & 187 & 100.0 \\
\hline
\end{tabular}

\section{Soft Skills}

Although soft skills refer to a wide range of abilities including flexibility, creativity, problem solving skills, listening skills, we have chosen those which have been found to be relevant to our area of interest, namely: communication skills, team building skills, leadership skills, stress management skills, time management skills, conflict management skills, trustworthiness and organizational effectiveness.

\section{Communication Skills}

Communication is the process of a sender transmitting a message to a receiver with mutual understanding; and the goals of communication are to influence, inform, and/or to express feelings. Hence, the importance of effective communication cannot be minimized as the goals of communication often affect our behaviour (Lussier, 1990). Human communication is considered to be the structure on which human relations are built and contributes toward long lasting relationships. If you are polite and friendly, chances are that others will in turn behave in a similar way towards you. However, if you are rude the other may retaliate, and thus may affect human relations either positively or negatively depending on the type of communication behaviour people indulge in.

\section{Team building skills}

Team building is a technique designed to help work- groups operate more effectively. These include various aspects such as clarifying objectives of the team and team members; identifying problems; developing skills; utilizing available resources; developing working relationships based on trust. Team building encourages team members to examine how they work together, identify their weaknesses, and develop more effective ways of cooperating (Newstrom \& Davis, 2002).

\section{Leadership skills}

Leadership is the process of influencing and supporting others to work enthusiastically towards achieving objectives. In order to be able to do this, leaders should possess Technical Skills 
(knowledge of and ability in any type of process or technique); Human Skills (ability to work effectively with people and to build teamwork); and Conceptual Skills (ability to think in terms of models, frameworks, and broad relationships, such as long-range plans).Recent developments in the area is linked to the work of Daniel Goleman (1995), who states that "effective leaders are alike in one crucial way: they all have a high degree of emotional intelligence". The five components of EI are self-awareness, self- regulation, motivation, empathy, and social skills.

\section{Stress management skills}

Stress can affect both physical and mental health. This is true among students who are sometimes confronted with undue pressure, when they have to meet deadlines in the submission of their assignments, projects or dissertations. Managing stress through different techniques and programmes: relaxation, exercises, diet, biofeedback, social support, personal wellness, counseling and others can help alleviate and even eliminate the effects of stress and stressors on individuals (Newstrom \& Davis, 2002).

\section{Time management skills}

The ability to effectively manage time through prioritizing and identifying and eliminating time wasters is the key to time management. Its one of the most important skills which students, like the ones we have identified for the research, need the most. Their biggest enemy of students is procrastination, a frequently used defense in the case of poor time-management techniques.

\section{Conflict management skills}

There are two types of conflict: - the ones which can be classified as constructive and/or functional or destructive and/or dysfunctional; a second classification is to see conflict as intraindividual, interpersonal, inter-group, intra-group or inter-organisational conflict. To resolve these types of conflict, one must identify their sources which can be due to individual differences, information sources, differing objectives and environmental factors (Lussier, 1990). Conflict resolution skills can prevent behaviours of team members from degenerating into irreconcilable situations that may prohibit them from ever working together productively again. (Newstrom \& Davis, 2002)

\section{Trustworthiness}

Continuing relationship requires some degree of trust - defined as the capacity to depend on each other's word and actions (Newstrom \& Davis, 2002). The existence and promotion of trust among students can only bring more benefits to the students themselves, and can also contribute towards avoiding conflicts. Trust is the basic requirement that can ensure the success of any human enterprise (Sukhoo, Barnard, Eloff, Van der Poll, \& Motah, 2005)

\section{Organizational Effectiveness}

Organizations "where people continually expand their capacity to create the results they truly desire, where new and expansive patterns of thinking are nurtured, where collective aspirations are set free, and where people are continually learning how to learn together" (Senge, 1990). It is believed that organisational effectiveness is achieved by working all human system variables together in a balanced way. By doing this, the organisation becomes an effective organisation and a learning organisation. When an organisation becomes a learning organisation, it takes an institutional permanence, and acceptable modes of behaviour become self evident to its members. Such shared meaning held by members of the organisation contributes to the establishment and reinforcement of organisational culture. 
As a six-year old organisation, we are in the construction phase, and as such, we are in the process of establishing and reinforcing a positive organisational culture. We are (as proposed by Farago \& Skyrme, 1995) giving due consideration to "Innovation and risk taking, attention to detail, people orientation, team orientation, outcome orientation, stability and positive aggressiveness". These characteristics are ever present in both staff and students and reflect the sense of purpose and commitment that one can witness in the every day life of the university.

\section{Intelligence}

Dr Howard Gardner, professor of education at Harvard University, developed the theory of multiple intelligences in 1983. The theory propounded that the traditional notion of intelligence, based on IQ testing, is far too limited. He instead proposed eight different intelligences to account for a broader range of human potential in children and adults. Gardner proposed the following eight MI which are employed in a variety of ways and a variety of settings, including work and educational settings. We have chosen the MI as proposed by Dr. Gardner for this paper and a questionnaire comprising questions investigating how these intelligences are interactive and how they work together was prepared and presented to students.

The following eight intelligences were proposed:

1) Linguistic intelligence has to do with the capacity to use words spoken or written when communicating (Gardner, 1983). Specifically linguistic intelligence helps to display a facility with words and languages and indicates the use of syntax, structure, semantics and the meaning of language

2) Logical-mathematical intelligence this type of intelligence has to do with inductive and deductive reasoning, and mathematical concepts. Definition of the logical -mathematical intelligence lays emphasis on reasoning capabilities, abstract pattern recognition, scientific thinking and investigation, and the ability to perform complex calculations.

3) Spatial intelligence deals with the perception of visual and spatial world

4) Bodily-kinesthetic intelligence helps people to acquire the expertise in using the whole body to express ideas and feelings, and the ability to building and making things.

5) Musical intelligence is built around the use of rhythms, music, and sounds to illustrate and communicate creative thinking

6) Interpersonal intelligence helps people to indulge in and foster successful relationships, and emphasizes sensitivity to others' moods, feelings, temperaments, and motivations and their ability to cooperate in order to work as a group.

7) Intrapersonal intelligence is one of the intelligences present in people who are believed to have more self-knowledge and tend to be more introspective, and cognitively and consciously self-aware, and prefer to work alone.

8) Naturalistic intelligence concerns people who have the capacity to recognise and make distinctions between the natural and the artificial dimensions of things in the world.

\section{Personality}

The concept of personality is so broad that it is difficult to define precisely. One definition that has stood the test of time was proposed by Allport (1937) who stated that Personality "is the dynamic organization within the individual of those psychophysical systems that determine his unique adjustments to his environment." Hollander (1971) gave a similar yet simpler definition when he wrote that personality is "the sum total of an individual's characteristics which make him unique". 
Among the authors who have proposed their own theories, the following are those that have and are still attracting the attention of personnel involved in educational and other sectors of human life.

According to Hollander (1971) perhaps the best way to understand personality is to look at its structure. Such a structure has been outlined and adapted to sub-fields of psychology. Personality, he stated, can be divided into three separate but related levels. These are (1) the psychological core, (2) role-related behaviours, and (3) typical responses.

The psychological core is further represented as being internal and consistent in nature, while typical responses and role-related behaviors are considered external and dynamic. The thickness or permeability of the layers that separate each level from the environment reflects the relative effect of the social environment on the three levels of personality. Permeability means the degree to which a membrane or dividing structure can be penetrated.

Role-related behaviors are most susceptible to the influence of the environment, while the psychological core is somewhat insulated from the environment. The psychological core of an individual holds that person's image of what she is really like. It includes the individual's selfconcept.

The psychological core represents the centerpiece of a person's personality; it includes basic attitudes, values, interests, and motives. In short, it's "the real you".

Typical responses represent the usual manner in which we respond to environmental situations. Typical responses are learned modes of dealing with the environment.

Role-related behaviours represent the most superficial aspect of our personalities. We engage in role-related behaviours to fit our perception of our environment.

Consequently, as the environment or our perception of it changes, our behaviours changes too.

\section{Theories of Personality}

Personality theorists, starting from the naïve personality theories, through the Greek personality theory based on bodily liquid, to C. Rogers, C. Jung, S. Freud, G. Allport, R. Cattell, H. Eysenck, L. Goldberg, and J. L. Holland have all proposed different definitions of personality, and have proposed different dimensions which make up personality.

\section{Psychodynamic theories}

Perhaps the most influential proponent of psychodynamic theory was Sigmund Freud (1933).Two distinguishing characteristics of the psychodynamic approach to personality have been its emphasis upon in-depth examination of the whole person, and its emphasis upon unconscious motives. In Freud's view, the id, ego, and superego form the tripartite structure of personality. The id represents the unconscious instinctual core of personality; in a sense, the id is the pleasureseeking mechanism. In contrast, the ego represents the conscious, logical, reality-oriented aspect of the personality. The superego represents the conscience of the individual; it is the internalized moral standards of society impressed upon the person by parental control and the process of socialization.

The individual's unconscious sexual and aggressive instincts are major determinants of behaviours, according to Freud. Aggression in human beings represents a potential example of this approach. 


\section{Behaviorist Theories}

The behaviorist school was developed by B.F. Skinner (1938). This theory emphasizes the "mutual interaction of the person with its environment". The contributions of John. B. Watson, father of American Behaviorism, and of I. P. Pavlov have greatly influenced these theories that explain personality in terms of reactions to external stimuli.

\section{Cognitive and Social Learning Theory}

From the viewpoint of social learning theory (Bandura, 1977), behavior is not simply a function of unconscious motives (as in psychoanalytic theory) or underlying predisposition. Rather, human behavior is a function of social learning and the strength of the situation. An individual behaves according to how she has learned to behave, as this is consistent with environmental constraints. If the environmental situation is prominent, the effect of personality traits or unconscious motives upon behavior should be minimal. Two of the primary mechanisms through which individuals learn are modeling and social reinforcement. Modeling, or imitative behavior, refers to the phenomenon of learning through observation. Social reinforcement is based upon the notion that rewarded behaviors are likely to be repeated. Martens (1975) has defined social reinforcement as verbal and nonverbal communication passing between two individuals that can increase the strength of a response.

\section{Humanistic Theory}

At the centre of the humanistic theory of personality is the concept of self-actualization (Maslow, 1998; Rogers, 1961). The human organism possesses an innate drive or tendency to enhance itself, to realize capacities, and to act to become a better and more self-fulfilled person. In the developing personality, openness to experiences that then shape the individual is of critical importance. It is not necessarily the experience that shapes the individual, but also the individual's perception of that experience. Self-actualization is an ongoing process of seeking congruence between one's experiences and one's self-concept.

\section{Trait Theories}

The basic position of trait or factor theory is that personality can be described in terms of traits possessed by individuals (Allport, 1937; Cattell, 1965; Eysenck \& Eysenck, 1968; Jung, 1921). These traits are considered synonymous with pre-dispositions to act in a certain way. Traits are considered to be stable, enduring, and consistent across a variety of differing situations. Those who exhibit the trait or need to achieve success, for example, can be expected to have a predisposition toward competitiveness and assertiveness in many situations.

Built on the work of Cattell and other traits theorists, Lewis Goldberg proposed a five dimension personality model, nowadays, known as the Big Five. This five-dimension personality model is subject to various research and has aroused the interest of professionals interested in personality psychology studies.

\section{The Measurement of Personality}

Cofer and Johnson (1960) identified three basic classes of measurement techniques. These are (1) rating scales, (2) unstructured projective tests, and (3) questionnaires.

\section{Rating Scales}

Characteristically, rating scales involve the use of a judge or judges who are asked to observe an individual in some situation. The judges employ the use of a checklist or scale that has been pre- 
designed for maximum objectivity. Usually, if the checklist is used properly and the judges are well trained, the results can be fairly reliable and objective.

Typically, two types of situations are involved in personality assessment using rating scales. These are the interview and the observation of performance. In the interview, the judge asks the subject numerous open-ended and specific questions designed to ascertain personality traits and general impressions. If the interview is conducted properly, carefully, and systematically, the results can be reliable and valid.

However, much depends upon the skill and sensitivity of the person conducting the interview. Observation of a subject during some type of performance situation is the second kind of rating system used for ascertaining personality. As with the interview, observations can be effective if the checklist being used is well designed and planned, and if the observer is highly trained.

Typically, for personality assessment, the checklist would contain specific traits and behaviors that the observer would look for.

\section{Projective Techniques}

Projective procedures may also be used to identify traits, but they are commonly used to determine information about underlying motives (Rorschach, 1947). Projective techniques allow subjects to reveal their inner feelings and motives through unstructured tasks. These unstructured techniques are used primarily in clinical psychology and are somewhat synonymous with the psychoanalytic approaches to explaining personality

\section{The Present Study}

For this study, we have chosen the "Big Five" factors as proposed by Lewis Goldberg. The Big Five model, built on the work of Raymond Cattell (1965) and Eysenck (1968) and proposed by Goldberg, is based on a considerable amount of empirical research. The Big Five factors which constitute a five dimension personality model is presented as follows:

\section{Extroversion -}

This dimension is described through the opposition of the concepts of "extroversion, expressed as: above; outgoing and physical-stimulation-oriented vs. introversion expressed as quiet and physical-stimulation-averse.

\section{Neuroticism}

Dimension which is explained through emotional stability: Calm, imperturbable, optimistic vs. emotionally reactive, prone to negative emotions

\section{Agreeableness}

Personality dimension described through positive aspects such as: Affable, friendly, conciliatory vs. negative aspects like aggressive, dominant, disagreeable

\section{Conscientiousness}

This dimension brings in play characteristics such as: Dutiful, planful and orderly vs. characteristics such as: spontaneous, flexible, and unreliable.

\section{Openness to experience}

The fifth dimension proposed deals with the presence of attitudes and aptitudes like: Open to new ideas and change vs. attitudes considered to be traditional and staid. 


\section{Results}

We have used the Computer program for analysis of data known as SPSS (Statistical Package for the Social Sciences) to analyze the data collected from the 187 questionnaires on the three concepts: Personality, Soft Skills and Multiple Intelligences. The results obtained are presented in the following pages.

\section{Soft Skills}

The soft skills used by the students indicate that Stress Management is the most important followed by Conflict Management and Leadership (See Figure 1). Organizational Effectiveness which is the next in importance is followed by Time Management, and Trustworthiness. Communication is the least important skills. It should be noted that the student population chosen for the study are from Information Technology and from Management.

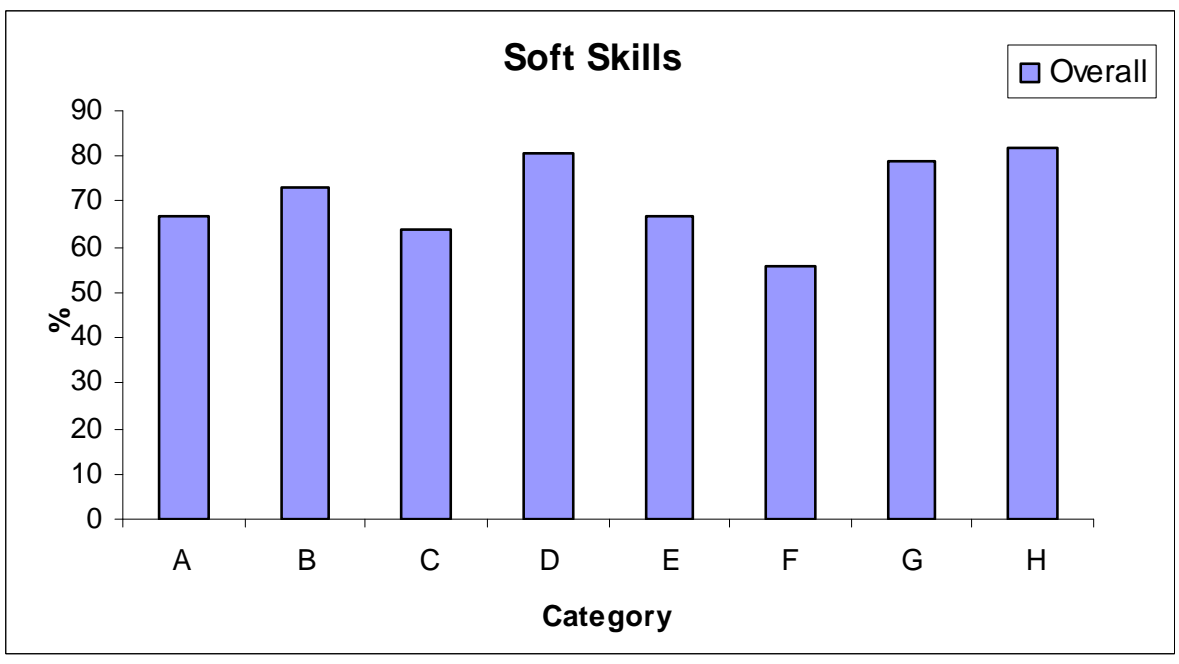

Figure 1: Use of Soft Skills

Note: The following categories have been used:
A: Communication
B: Team work
C: Leadership
D: Stress management.
E: Time Management
F: Trustworthiness
G: Conflict Management
H: Organizational Effectiveness

\section{Intelligence}

The responses of the 187 students to the questionnaire on personality yielded the following results, presented in the form of the bar chart in Figure 2, illustrating the importance given to each of the intelligences among the students. We have not made any gender discrimination as both male and female students have to follow the same lecturers, carry out the same assignments and, learn under the same conditions.

From the chart in Figure 2 it appears that the distribution of the types of intelligences used, namely logical mathematical, body-kinesthetic, interpersonal, intrapersonal intelligences are the most evident among all students; spatial and musical intelligences are less important for some of them; while linguistic and naturalistic intelligences receive less interest and surprisingly, the linguistic intelligence is found at the lowest level. 


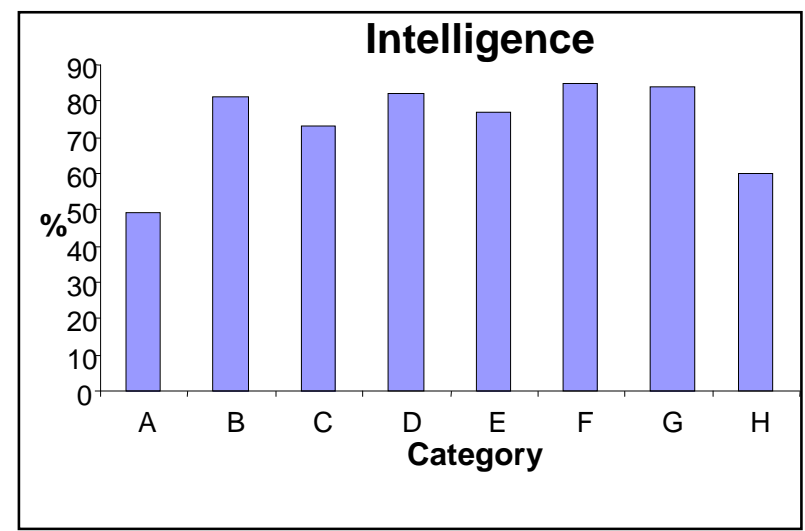

\section{Figure 2 - Multiple Intelligences distribution among student sample}

The use of multiple intelligences among the student population
A: Linguistic intelligence
B: Logical-mathematical intelligence
C: Spatial intelligence
D: Bodily-kinesthetic intelligence
E: Musical intelligence
F: Interpersonal intelligence
$\mathrm{G}$ : Intrapersonal intelligence
$\mathrm{H}$ : Naturalistic intelligence

The use of the logical-mathematical, spatial intelligence, body-kinesthetic, musical intelligence, Interpersonal, intrapersonal, intelligences by the students, irrespective of their fields of study shows that these are commonly used intelligences among students, and in our opinion needs to be further investigated to discover the reasons for their use and how these students could be helped in their academic endeavors.

The low percentage of linguistic and naturalistic intelligences in the overall graphic representation reflect the influence of a lower use of these two types of intelligences by the group of students studying in the field of information technology.

\section{Personality}

For this study, we have chosen the five-dimension personality model proposed by Lewis Goldberg as mentioned earlier. Table 2 shows the value of each of the five dimensions among the student population concerned in the study.

Table 2 - Correlations between Personality

\begin{tabular}{|c|c|c|c|c|c|}
\hline Positive correlation & Extroversion & Neuroticism & Agreeableness & Conscientiousness & $\begin{array}{l}\text { Openness } \\
\text { to Experience }\end{array}$ \\
\hline Communication & - ve & 0.035 & 0.008 & - ve & - ve \\
\hline Team work & - ve & 0.055 & 0.021 & - ve & - ve \\
\hline Leadership & - ve & 0.214 & 0.077 & - ve & 0.045 \\
\hline Stress Management & -ve & 0.043 & - ve & - ve & 0.009 \\
\hline Time Management & - ve & - ve & - ve & - ve & - ve \\
\hline Trustworthiness & -ve & 0.021 & - ve & - ve & - ve \\
\hline Conflict Management & - ve & 0.082 & 0.017 & - ve & - ve \\
\hline $\begin{array}{l}\text { Organizational Effec- } \\
\text { tiveness }\end{array}$ & $-\mathrm{ve}$ & 0.075 & 0.036 & 0.034 & - ve \\
\hline
\end{tabular}


We have considered only traits that show positive correlation and disregarded the negative ones. The dominant traits among the students are: Neuroticism, Conscientiousness, Agreeableness, Extroversion, and Openness to experience all being on the average dominant traits as per Table 2.

\section{Personality/Soft skills}

Table 2 shows the correlations between personality and soft skills. The Neuroticism dimension is the one which has positive correlations with seven out of the eight soft skills as shown in the table. Therefore, with the exception of Time Management, a person Neuroticism positive traits (calm, imperturbable, optimistic), would be prone to be positively influenced by soft skills such as leadership, conflict management, organisational effectiveness, team work, stress management, communication and trustworthiness.

Agreeableness which is the next trait with positive correlations in relation to five out of the eight soft skills, indicate that a person with affable, friendly and conciliary personality traits would feel comfortable with soft skills like leadership, organizational effectiveness, team work, conflict management, and communication. A person possessing the Openness to experience trait would be influenced by leadership and stress management soft skills, and someone with Conscientiousness personality dimension will be interested in organizational effectiveness as soft skill. There seem to be no positive correlation between people with extroversion personality dimension - above; out-going and physical-stimulation-oriented, and the eight soft skills, (needs further investigation to find reasons for such characteristics).

\section{Soft Skills/Personality}

An analysis of the correlation between soft skills and personality shows that organizational effectiveness is a common soft skill for persons with neuroticism, agreeableness and conscientiousness as personality traits. Leadership as soft skill is common to the following personality traits: neuroticism, agreeableness, and openness to experience. Conflict management, team work and communication, are soft skills which are common to both neuroticism and agreeableness. Leadership and stress management are soft skills common to persons open to new ideas and change. All negative correlation between the eight soft skills and extroversion personality dimension has been recorded and will be the major area of investigation for future research.

There is little doubt that there is a relationship between personality, intelligence, and the use of soft skills. Moreover, the correlation coefficients are very low positive coefficients and further study is required to identify these relationships and provide lecturers and other personnel involved in the learning process of students better insight in how students' personality and intelligences affect their choice of learning activities and learning tools.

\section{Conclusion}

The study group offered wide possibilities for investigating personality, intelligences and soft skills, and to identify the issues and perspectives which impinge on the role of educators. Much more extensive research is required in order to gain as full a picture as possible of the variety of personality and intelligence factors that impact on the academic performance of students. We believe that, it is only by conducting concerted research that the pedagogical activities of educators, lecturers and teachers can be validated and adjusted specifically to meet the needs of the student population.

The methodology used can still be reviewed and the tools used to investigate data can be revisited. In view of the rate of failures at various levels of the education system, there is need for research to identify the factors behind such state of affairs and remove the causes which replicate such situations year in and year out. 
The use of multiple intelligences is crucial for students and is essential to ensure their success in their studies. The effect of personality factors on the behaviours of people cannot be underestimated, as their influence is everlasting. Research need to be carried out to explore the constraints that limit the use of the Soft skills identified and investigated in the present paper. The need to develop an insight into the competence of educators, lecturers and teachers so as to be able to recognize whether they possess the necessary knowledge on subjects like personality and intelligence, and whether they can use this knowledge for the benefit of their students.

The research identifies some urgent issues confronting educators. Some of them can find useful areas for further research and contribute to a better understanding of the concepts underlined in this paper.

\section{References}

Allport G. W. (1937). Personality - A psychological interpretation. New York: Holt \& Co.

Bandura, A. (1977). Social learning theory. Englewood Cliffs, NJ: Prentice-Hall.

Cattell, R. B. (1965). The scientific analysis of personality. Baltimore: Penguin.

Cofer, C. N., \& Johnson, W. R. (1960). Personality dynamics in relation to exercise and sport. NY: Harper.

Eysenck, H. J., \& Eysenck, S. B.G (1968). Eysenck personality inventory. London: London University Press.

Farago, J. \& Skyrme, D. (1995). The learning organisation. Retrieved from http://www.skyrme.com/insights/3lrnorg.htm

Freud, S. (1933). New introductory lectures on psychoanalysis. New York: Norton.

Gardner, H. (1983). Frames of mind: The theory of multiple intelligence. New York, NY: Basic Books.

Goleman, D. (1995). Emotional intelligence. New York, NY: Bantam Books.

Goleman, D. (1998). Working with emotional intelligence. New York, NY: Bantam Books.

Jung, C. G. (1921). Psychological types. Princeton, NJ: Princeton University Press.

Hollander, E. P. (1971). Principles and methods of social psychology (2nd ed.). New York: Oxford University Press.

Lussier, R.N (1990). Human relations in organisations - A skill building approach. Irwin.

Martens, R. (1975). Social psychology and physical activity. New York: Harper \& Row.

Maslow, H. A (1998), Maslow on management. John Wiley \& Sons.

Newstrom, J. W., \& Davis, K. (2002). Organisational behaviour - Human behaviour at work. McGrawHill Irwin.

Rogers, C. R. (1961). On becoming a person. Boston: Houghton Mifflin.

Rorschach, H. (1947). Psycho diagnostic (5th ed.). Presses Universitaire de France. Reprinted 1976.

Senge, P. (1990). The fifth discipline: The art \& practice of the learning organization. London: Century Business.

Skinner, B. F. (1938). The behaviours of organisms: An experimental analysis. NY: Appleton-CenturyCrofts.

Skinner, B. F, (1953). Science \& human behaviours. New York: McMillan.

Sukhoo, A., Barnard, A., Eloff, M. Van der Poll, J. A., \& Motah, M. (2005). Accommodating soft skills in software project management. Issues in Informing Science and Information Technology, 2, 691-703.

Retrieved from http://proceedings.informingscience.org/InSITE2005/I55f42Sukh.pdf. 


\section{Biography}

Dr. Mahendrenath, MOTAH is Senior Lecturer at the University of

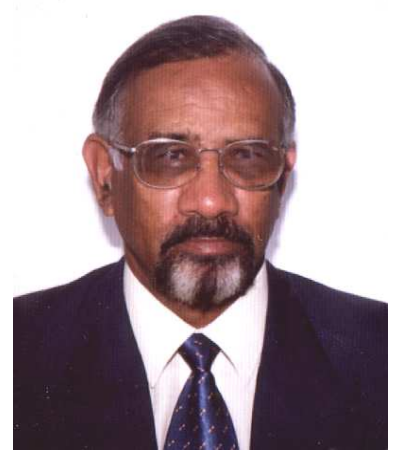
Technology, Mauritius. He has a PhD in Arts and Human Sciences from Paris VII, Jussieu University, Paris, France. He has spent one month in USA, as a Visitor under USIA in June 1987. He also attended the Laurentian University, Sudbury, CANADA in connection with the Distance Education Links Project, under CIDA in June 1995. He has participated in various Workshops, Seminars and Conferences at National and International levels.

He has extensive experience in the fields of Management, Administration and Training at both National and International levels. He is Chairperson of the Regional Centre for Urgent Anthropological and Ethnological Research. He has been appointed as Psychologist on the Monitoring Committee on the Protection of Elderly Persons Act, 2005and is solicited to act as Resource Person in Consultancies and Training from Ministries and NGOs in Mauritius and the Outer Islands. He has presented papers at various International conferences in USA, Portugal, UK, Slovenia 